\title{
Del Partido Comunista al Partido Comunista Comité Nacional de Recuperación Revolucionaria en la Argentina de los años sesenta. Una escisión con marca universitaria
}

\author{
From the Communist Party to the Communist Party - National \\ Committee of Revolutionary Recovery in 1960s Argentina. A split \\ marked by university politics.
}

Juan Sebastián Califa*

\begin{abstract}
Resumen
A mediados de 1967 tuvo lugar la mayor ruptura con la juventud en el seno del Partido Comunista Argentino, hasta entonces la más nutrida formación política de la izquierda de este país. Dado que los universitarios encabezaron este proceso de escisión, resulta central interrogarse por lo sucedido en ese mundo estudiantil para explicarlo. Este artículo se concentrará en lo acaecido en la Universidad de Buenos Aires, ya que en esta ciudad y en esta institución se dio su epicentro. Para dar cuenta de las razones de este divorcio político me remitiré no sólo a los documentos en los que se explicitó la polémica partidaria, sino también a otras fuentes que permiten reconstruir la coyuntura universitaria determinante en que se desarrolló la escisión.
\end{abstract}

Palabras Claves: comunismo, juventud, universidad, ruptura

\begin{abstract}
In mid 1967 the biggest rupture with the youth faction occurred within the Argentine Communist Party, until then the most numerous left-wing political party in the country. Since it was university groups that spearheaded this split, it is crucial to examine the inner workings of the process in this sphere. This article focuses on the University of Buenos Aires, given the central role of the capital city and its flagship higher education institution in the events. To account for the reasons for this political divorce I will refer not just to the documents where the conflict became explicitly fleshed out but also other sources that allow to reconstruct the circumstances giving rise to the split.
\end{abstract}

\footnotetext{
* Argentino. Licenciado en Sociología (FSOC-UBA), Magister en Sociología de la Cultura (IDAESUNSAM) y Doctor en Ciencias Sociales (FSOC-UBA). Investigador del CONICET con sede en el Instituto de Historia Argentina y Americana Dr. "Emilio Ravinani" (FFYL-UBA y CONICET). Miembro del proyecto UBACYT "Políticas públicas, universidad y movimiento estudiantil: 1969-1985" (Programación 2014-2017, código 200201301100187BA) bajo la dirección del Dr. Pablo Buchbinder (FSOC-UBA).
} 
Keywords: communism, youth groups, university, rupture

\section{Introducción}

En los últimos años se han incrementado ostensiblemente los estudios dedicados al Partido Comunista durante el siglo XX en todo el mundo. De este modo, se ha ido saldando desde las ciencias sociales un agujero historiográfico sumamente relevante de completar dada la importancia que gozaron estas formaciones políticas amparadas, y guiadas en buena medida, por la extinta Unión Soviética. La Argentina no ha sido una excepción al respecto. En este país, en sintonía con dicho fenómeno, es cada vez mayor la producción académica, y también periodística, abocada a indagar sobre distintos aspectos del Partido Comunista Argentino (PCA) en el siglo pasado. Los intelectuales, los jóvenes, los líderes partidarios, el movimiento obrero dirigido y conformado en torno a esta organización han sido objetos de variados estudios.

En paralelo a este proceso, también el movimiento estudiantil en la Argentina ha sido revalorizado como objeto de estudio. Si bien en esta indagación la intensidad analítica no es tan pareja en todo el globo y en Latinoamérica específicamente, siendo México otro país donde esta clase de estudios se han desarrollado con sistematicidad, no es desdeñable la labor de la última década. Teniendo como antecedente más significativo los trabajos realizados al calor del aumento de la conflictividad universitaria en los años sesenta y setenta tras a prosperidad de posguerra, los actuales estudios han revisitado este período de un modo más puntilloso como lo demuestran los meticulosos estudios de casos que sostuvieron tal indagación. El trabajo de detección y análisis de fuentes ha arrojado una serie de conocimientos que diferencian estos trabajos de los de la primera ola, puesto que en estos primeros la mirada macro soslayaba el análisis micro detallado y ligado a las fuentes. El desafío actual reside en poder construir una síntesis global, esta vez bajo la ventaja que otorga el conocimiento acumulado.

Este artículo se ubica precisamente en la intersección entre ambos campos de estudio. Ello es así porque el objeto de análisis de este trabajo como se verá, la ruptura del PCA a fines de los años sesenta del siglo XX, tuvo un sujeto preponderante y casi excluyente en la juventud universitaria. Si bien otros trabajos han señalado esta ruptura clave en el itinerario político de este partido, hasta aquí no existen estudios académicos específicos abocados a la indagación de este divorcio político que prologó el ascenso de izquierdas militante más significativo que tuvo la Argentina. Las páginas que siguen tratarán de responder a los interrogantes sobre las razones y el desarrollo de esta escisión así como de referir sus consecuencias inmediatas.

Dado que es insoslayable el contexto de conflictividad y los enfrentamientos sociales propios de los universitarios que conllevaron a esta separación partidaria, este artículo necesariamente se imbuye en tales confrontaciones. En ese sentido, antes de zambullirse a los documentos de la ruptura, se saca a luz la coyuntura universitaria en que la misma se gestó. Para ello, se han privilegiado las fuentes primarias que permiten recrear los enfrentamientos sociales que marcaron el derrotero del movimiento estudiantil y particularmente de la militancia comunista. Finalmente, en relación a la ruptura en sí misma la intención en este trabajo radica en ubicar los pormenores de lo dicho en los documentos que ésta hizo aflorar en el contexto de tal conflictividad universitaria, alejándose así de un mero análisis discursivo. Precisamente, la principal hipótesis de trabajo a demostrar sostiene que sin un entendimiento acabado de la coyuntura universitaria y del desenvolvimiento de la militancia comunista en ésta no es posible dar cuenta cabalmente de esta escisión en el seno del PCA. 
Por último, aclárese que si bien este trabajo plantea una perspectiva general, y una tesis también global desde donde analizar la ruptura en su conjunto, el análisis concreto se dirige aquí hacia un caso específico: lo acaecido en la Universidad de Buenos Aires (UBA). Esta casa de estudio, que concentraba más de la tercera parte de la matrícula universitaria argentina, emplazada en la Capital Federal, centro político del país, constituyó el epicentro de la ruptura juvenil con el PCA. Ello fue así porque desde esta institución la militancia comunista había conquistado posiciones dirigentes en el movimiento estudiantil argentino, siendo un verdadero baluarte para el PCA desde donde desarrolló la Federación Juvenil Comunista (FJC). De este señalamiento espacial de la fuerza juvenil comunista queda en claro que cualquier fractura allí iba a repercutir y arrastrar al resto de la organización juvenil. Dado que así ocurrió, abocarse a lo sucedido en la UBA es una tarea central que aquí se emprenderá.

\section{El PCA y los convulsionados años sesenta}

La autoproclamada "Revolución Libertadora" tras derrocar al gobierno peronista durante 1955 fue sucedida tres años después por el gobierno de constitucionalidad emparchada del radical intransigente Arturo Frondizi quien luego de casi cuatro años al frente del Poder Ejecutivo resultó reemplazado por un senador de su partido, José María Guido. Mediante esta operación golpista las fuerzas armadas que la promovieron intentaron conservar la formalidad constitucional. Esta operación fue seguida de un nuevo llamado a elecciones en 1963, manteniéndose la proscripción a Juan Domingo Perón, que consagraron presidente con escasa cosecha de votos el radical del pueblo Arturo Illía, a quien un nuevo golpe de Estado impidió completar su mandato tres años más tarde. Estos hechos, sobre los cuales la historia argentina ofrece con su trascurrir nuevas evidencias, conllevan a un razonamiento básico de los estudiosos del período: el rasgo característico del sistema político argentino en los años sesenta reside en su inestabilidad. Ello, sumado a las crisis económicas con que estas convulsiones políticas se entrelazaban, permite visualizar el terreno pantanoso en que se desenvolvió la política argentina.

En el comienzos de estos vertiginosos años sesenta el PCA tuvo en su rama juvenil, entre la que sobresalían los universitarios, uno de sus sectores más enérgicos. ${ }^{1}$

\footnotetext{
${ }^{1}$ Respecto al PCA en estos primeros sesenta desde hace más de una década vienen apareciendo una serie de artículos que si bien no llegan a tener la profundidad de una obra de conjunto sirven no obstante para empezar a cubrir el hueco historiográfico existente. Véase María Cristina Tortti. "Izquierda y 'nueva izquierda' en la Argentina. El caso del Partido Comunista”. Sociohistórica. Cuadernos del CISH, n 6, Centro de Investigaciones Socio-Históricas, Facultad de Humanidades y Ciencias de la Educación, UNLP. La Plata: Al Margen, $2^{\circ}$ semestre de 1999, pp. 221-232 y "Debates y rupturas en los partidos Comunistas y Socialista durante el frondizismo". Prismas. Revista de historia intelectual, UNQui, nº 6. Quilmes, 2002, pp. 265-274; Hernán Camarero. "Tras las huellas de una ilusión: El Partido Comunista Argentino y sus planteos del Frente Democrático Nacional (1955-1963)". Archivos de historia del movimiento obrero y la izquierda, año III, $n^{\circ} 5$. Buenos Aires, septiembre de 2014, pp. 31-50. En relación a la historiografía general referida al PCA consúltese Jorge Cernadas; Roberto Pittaluga y Horacio Tarcus. "La historiografía sobre el partido comunista de la Argentina. Un estado de la cuestión". El Rodaballo. Revista de política y Cultura, año IX, no 8. Buenos Aires, otoño-invierno de 1998, pp. 30-39; Hernán Camarero. "La izquierda como objeto historiográfico. Un balance de los estudios sobre el socialismo y el comunismo en la Argentina". Nuevo Topo. Revista de Historia y Pensamiento Crítico, $\mathrm{n}^{\circ}$ 1. Buenos Aires, septiembre-octubre de 2005, pp. 77-99; Daniel Campione. "El Partido Comunista de la Argentina. Apuntes sobre su trayectoria". Elvira Concheiro Borquez, Massimo Modonesi y Horacio Crespo (coords.). El comunismo: otras miradas desde América Latina. México D.F.: UNAM, 2007, pp. 167-215.
} 
Las estimaciones más osadas desde el partido sostenían que se habían alcanzado las 100.000 afiliaciones a comienzos de la década. ${ }^{2}$ Si bien esto ha sido puesto en duda, siendo probable que el crecimiento partidario existiera pero no a ese nivel, es destacable que desde la dirección comunista la juventud universitaria era señalada como una fuente de dinamismo. ${ }^{3}$ La Universidad recaía en parte dentro del mundo intelectual dentro del cual este partido siempre había tratado de conquistar influencia, contando con una significativa minoría y una plétora de iniciativas culturales que le granjeaban cierto reconocimiento. ${ }^{4}$ Los esfuerzos supremos del partido recaían, no obstante, en la conquista de la clase obrera. Si bien el PCA seguía contando con influencia en el movimiento laboral, ésta se veía restringida por el freno que le imponían las mayorías sindicales asumidas peronistas tras cuya dirección se alineaba el grueso de los trabajadores. El golpe que le había asestado al partido el gobierno peronista, se constituía pues en un desafío a revertir. Para ello, resultaba fundamental contar con una organización unificada y coherente, se razonaba, lista para actuar en el terreno político cuando en este se desataran grandes convulsiones. El aporte a las filas partidarias de los universitarios no era entonces nada desdeñable.

Prueba de su ascenso en las filas estudiantiles fue la conducción del partido, junto a aliados que le eran cada vez más próximos, de la Federación Universitaria Argentina (FUA) que conquistó a principios de los años sesenta. Los comunistas en el mundo universitario integraban el reformismo, esto es, el sector universitario que se reconocía heredero de la Reforma Universitaria de 1918. Pregonaban, en ese sentido, la autonomía universitaria y el cogobierno estudiantil de las casas de altos estudios. Pero no sólo sostuvieron esa identidad universitaria formando parte de las agrupaciones que le daban vida, sino que también en buena medida se encargaron de actualizarla. La centralidad que adquirió en los sesenta la cuestión de la unidad obrera-estudiantil en el joven reformismo conformó en cierto modo parte del programa político que los comunistas renovaron. Así, bajo esa identidad política reformista, que ya sustentaban con firmeza desde la década de 1930, éstos incrementaron su influencia en la juventud universitaria.

La UBA, que concentraba como ya se dijo más de la tercera parte de la matrícula universitaria nacional -alrededor de 200.000 estudiantes a mediados de los sesenta- resultó clave en este proceso de ascenso militante. ${ }^{5}$ Tras el golpe de Estado de 1955, las universidades recuperaron su autonomía. Así, el rector era designado por la asamblea universitaria y ya no por el Poder Ejecutivo, estando todo el sistema de dirección basado en el cogobierno universitario (profesores, graduados y estudiantes

\footnotetext{
${ }^{2}$ Tortti. "Izquierda y 'nueva izquierda'....", p. 223.

${ }^{3}$ Camarero cuestiona este crecimiento al mostrar que no existen evidencias empíricas más allá de las proclamaciones partidarias. "Tras las huellas... ", p. 34.

${ }^{4}$ Sobre los antecedentes universitarios del PCA véase Marcelo Caruso. "La amante esquiva: comunismo y reformismo universitario en Argentina (1918-1966). Una introducción". Renate Marsiske (comp.). Movimientos estudiantiles en la historia de América Latina, volumen II. México D.F.: Plaza y Valdés, 1999, pp. 123-162 y más cerca en el tiempo de mi autoría "Los estudiantes comunistas frente a la reestructuración de la Universidad de Buenos Aires (1955-1958)”. Estudios Sociales, año XX. Santa Fe: Universidad Nacional del Litoral, primer semestre de 2010, pp. 127-150. Desde la perspectiva de un importante dirigente estudiantil de esta corriente véase Bernardo Kleiner. Veinte años del movimiento estudiantil reformista 1943-1963. Buenos Aires: Platina, 1964.

${ }^{5}$ En mi tesis doctoral referida al movimiento estudiantil de esta casa de altos estudios en dicho periodo he explicado cómo este ascenso se produjo, y la centralidad que en este temprano proceso de radicalización militante le cupo a los universitarios comunistas. La misma ha sido publicada como Reforma y Revolución. La radicalización política del movimiento estudiantil de la UBA 1943-1966. Buenos Aires: Eudeba, 2014.
} 
participaban, con preeminencia de los primeros, de los consejos que decidían los destinos universitarios). En este marco, la UBA se destacó por la inédita modernización que encaró, la que trajo aparejada un desarrollo científico inédito que aunque no fue parejo y ni siquiera mayoritario, no dejo de ser significativo. El movimiento estudiantil de signo reformista mayoritario ocupó un papel destacado en este proceso aunque sus acuerdos con las autoridades docentes cedieron lugar a las tensiones de modo creciente, dando cuenta estas pujas de la radicalización estudiantil del período.

En esta casa de estudio, "los bolches" vieron crecer desde fines de los años cincuenta su poder de convocatoria, llegando a la dirección de muchos centros de estudiantes y alcanzado, cuando no, minorías significativas. Los consejos directivos de las facultades contaron asimismo con representantes de esa tendencia que, dado su peso en éstos, recalaron también en el consejo superior. El epicentro de este proceso tuvo lugar en la Facultad de Medicina porteña donde los comunistas dominaban con holgura el centro local, siendo además mayoría entre los consiliarios estudiantiles. Las principales movilizaciones de la época, como las luchas presupuestarias en 1964 o las movilizaciones contra el envío de tropas a la intervención estadounidense en Santo Domingo un año más tarde, encontraron en estos jóvenes comunistas su vanguardia. Si a fines de los cincuenta se habían presentado motorizando el reformismo de "izquierda" en detrimento de otra sección de esta fuerza caracterizada como de "derecha", sector este último más identificado con el antiperonismo liberal, a mediados de los sesenta reformismo e izquierda conformaban una identidad política más compacta. Ello ofrecía nueva evidencia del avance de los comunistas entre las juventudes universitarias.

Las desavenencias de la FJC con la dirección partidaria no fueron ajenas en estos años de crecimiento. Silvia Sigal, ha mostrado también que con el paso de los años sesenta el PCA fue perdiendo su hegemonía cultural en la izquierda. ${ }^{6}$ La aparición de revistas como El escarabajo de oro o El grillo de papel sacaron a la luz tempranamente este fenómeno. Entre los jóvenes la primera ruptura significativa se produjo en la provincia de Córdoba durante 1963. Allí los universitarios comunistas acompañaron precisamente una escisión que ocasionó la intelectualidad del partido, la que dio vida al grupo nucleado en torno a Pasado y Presente, otra revista que se haría célebre en el campo intelectual de la época. ${ }^{7}$ Esta ruptura fue seguida al año siguiente por otra, esta vez más puramente juvenil, con epicentro en la Universidad porteña: Vanguardia Revolucionaria se denominó el grupo escindido. En Córdoba la escisión resultó más significativa para el PCA que en Buenos Aires ya que en la capital argentina el grupo separado rápidamente se esfumó y la FJC local se recobró rápidamente, cosa que no pudieron hacer sus pares cordobeses con la misma celeridad. Más allá de la contabilidad precisa de los daños ocasionados por ambos disidentes, que en ningún caso llegaron a ser tan significativos como los que vendrían, estas divergencias, que no fueron las únicas aunque sí las más significativas, exteriorizaron el malestar reinante en la filas de la FJC con la dirección del PCA. En esos años fue común criticar la pérdida de dinamismo revolucionario de dicha dirección, un terreno en que, así razonaban sus críticos, el PCA debía destacarse. Sin embargo, los que partieron no prosperaron en el terreno político, con lo cual el nivel de competencia al partido resultó sumamente limitado.

Más globalmente estas disidencias deben ubicarse dentro de los efectos locales que disparó la Revolución Cubana, la cual puso en tela de juicio las vías revolucionarias

\footnotetext{
${ }^{6}$ Intelectuales y poder en la década del sesenta. Buenos Aires: Puntosur, 1991, p. 107.

${ }^{7}$ Al respecto véase Roberto Ferrero. Historia Crítica del Movimiento Estudiantil de Córdoba tomo III (1955-1973). Córdoba: Alción, 2009, pp. 107-164.
} 
a seguir en Argentina. Los debates que se abrieron afectaban a una dirección partidaria convencida de su arquitectura estratégica, plasmada en la consigna del Frente Democrático-Popular, que preveía la revolución democrático-burguesa, agraria y antiimperialista, como una etapa necesaria antes de alcanzar el socialismo. La vía pacífica que en la práctica impuso fue uno de los puntos de disidencia fundamentales con el resto de una izquierda cada vez más radicalizada. ${ }^{8}$ Sin embargo, estas desavenencias tendieron a acallarse hacia adentro del partido, no sólo por el hecho de que las expulsiones y deserciones suprimieron un debate interno de más largo plazo, sino también porque los escépticos prefirieron mantener el silencio para así priorizar la unidad partidaria. Como ha mostrado Isidoro Gilbert, si bien desde la dirección del PCA, advirtiendo tensiones a mediados de los años sesenta, se movieron para impedir la llegada de los más remisos a la dirección de la FJC, éstos aplazaron la polémica hasta encontrar las circunstancias en que se hiciera adecuado difundirlas. ${ }^{9}$

No obstante lo anterior, los inquietos jóvenes comunistas no pensaban en un divorcio sino, más bien, en entablar un proceso de debate que permitiera una renovación partidaria. "Ganar al partido desde adentro" era su objetivo en última instancia. Muy distinta resultó esta situación en comparación con lo que había sucedido a mediados de los años sesenta con el Partido Socialista: para entonces, impulsado por sus sectores juveniles cada vez más radicalizados, éste no pararía de escindirse. ${ }^{10}$ Por ende, no había nada inevitable que ya planteara el accionar de la juventud comunista. La historia estaba abierta, cualquier cosa podía ocurrir. Como trataré de demostrar en las páginas que siguen, las circunstancias que se produjeron tras el golpe de Estado de 1966 con la represiva intervención universitaria que el gobierno de facto impuso fueron claves en la gestación de la escisión más significativa en la historia del PCA.

\section{El golpe de Estado de 1966 y la intervención universitaria}

El 28 de junio de 1966 asumía la presidencia tras el golpe de Estado el general retirado Juan Carlos Onganía, liderando el autoproclamado gobierno de la "Revolución Argentina". En su asunción se hizo presente un amplio abanico de personalidades que incluía figuras destacadas del mundo empresario junto a gremialistas de fuste como el líder de la Confederación General del Trabajo (CGT), Augusto Vandor. Guillermo O' Donnell denominó "consenso de terminación" a la amplia unidad gestada en torno al objetivo de acabar con el régimen político constitucional presidido por Arturo Illia, unidad que no preveía acuerdos en relación al nuevo régimen por construir. ${ }^{11} \mathrm{El}$ comando militar se ocupó meticulosamente en identificar esas jornadas con una imagen de eficiencia, que contrastara con la etapa anterior, asociada con la impronta que se pretendía para el gobierno. Se iniciaba así lo que muchos analistas del período

\footnotetext{
${ }^{8}$ Sobre este asunto véase Laura Prado Acosta: “Sobre lo 'viejo' y lo 'nuevo': el Partido Comunista Argentino y su conflicto con la Nueva Izquierda en los años sesenta". A Contracorrientes. A Journal on Social History and Literature in Latin America, North Carolina State University, vol. 11, $\mathrm{n}^{\mathrm{o}} 1$. North Carolina: Raleigh, pp. 68-85 y Alexia Massholder: El Partido Comunista y sus intelectuales. Pensamiento y acción de Héctor P. Agosti. Buenos Aires: Ediciones Luxemburg, 2014, p. 257 y ss.

9 Este señalamiento aparece en numerosas ocasiones a lo largo de La Fede. Alistándose para la revolución, La Federación Juvenil Comunista 1921-2005. Buenos Aires: Sudamericana, 2009.

${ }^{10}$ María Cristina Tortti estudió esto en El 'viejo' Partido Socialista y los orígenes de la 'nueva izquierda (1955-1966). Buenos Aires: Prometeo, 1999.

11 "Estado y alianzas en la Argentina". Desarrollo Económico. Revista de Ciencias Sociales, vol. 16, nº 64. Buenos Aires, enero-marzo de 1977, pp.523-554, p. 161.
} 
denominaron "modernización autoritaria", etapa en la que el "tiempo político" quedaría supeditado a los objetivos trazados para el "tiempo económico". En ese sentido, el horizonte gubernamental de largo plazo requerido por las tareas a emprender singularizaba el proyecto de estos golpistas respecto a sus antecesores marcados por el signo provisorio con que habían encarado sus funciones. Aunque al momento del golpe y por algunos meses fue difícil señalar con exactitud qué fracción de la burguesía encabezaba el proyecto gubernamental, pronto esto se hizo evidente: los monopolios industriales trasnacionales. Así, según Juan Carlos Portantiero: “... se trata del intento más decidido realizado hasta hoy por la fracción dominante en el nivel económicosocial, para superar a su favor una situación de crisis orgánica y transformar ese predominio en hegemonía."12 En ese contexto, sobresalió, por su carácter excepcional, el activo repudio a este gobierno de facto de parte del PCA, que lo juzgó desde sus inicios un instrumento del imperialismo y al gran capital nativo. ${ }^{13}$

En el terreno universitario el impacto del golpe fue enorme. El derrotero de activación política estudiantil de los últimos años que había marcado a estas casas de estudio públicas, lapso en el que la consigna impulsada por los comunistas "más presupuesto universitario y menos presupuesto militar" había establecido claramente el enemigo del joven reformismo, constituía motivo suficiente de indignación para el nuevo Ejecutivo. La Universidad constituía en ese sentido un territorio hostil. En lo inmediato poco importaba erigirla como baluarte de modernización social. Antes de encarar esa labor era prioritario imponer el orden en sus aulas. Finalmente, el viernes 29 de julio de 1966 el decreto-ley 16.912 firmado por Onganía dispuso, intentando acotar el impacto negativo de la medida, que los rectores y decanos universitarios pasaran a ser designados por el Poder Ejecutivo en carácter de administradores. Sin embargo, excepto en las casas de altos estudios más pequeñas (del Sur, Cuyo y Nordeste), los rectores de las otras seis universidades nacionales se negaron y debieron dejar sus cargos.

La medida atacaba la democracia interna de las casas de altos estudios al desconocerles legitimidad e injerencia a sus órganos gubernamentales. Anulaba así instancias de cogobierno como la asamblea universitaria, el consejo superior y los consejos directivos que decidían los destinos de cada facultad. Se daba por tierra con toda la institucionalidad construida bajo el ideario de la Reforma. Tras la intervención, que en esta casa tomó ribetes dramáticos con los episodios de violencia policial que alcanzaron su epicentro en la Facultad de Ciencias Exactas y Naturales durante la llamada "Noche de los Bastones Largos", cualquier posibilidad de continuidad institucional quedó anulada. El cambio a los bastonazos mostró la determinación del Ejecutivo para imponer sus prerrogativas sobre estas verdaderas "cuevas de comunistas". Entre la pléyade de grupos estudiantiles opositores, los comunistas en Buenos Aires asumieron el mayor protagonismo.

A comienzos de agosto de 1966 el gobierno decretó la suspensión de clases en las universidades nacionales por los próximos quince días. En la UBA, a medida que se iban liberando a los estudiantes detenidos se incrementaba la vigilancia policial en todas sus dependencias. ${ }^{14}$ En este clima represivo la FUA, dirigida por los comunistas, emitió

\footnotetext{
12 "Clases dominantes y crisis política en la Argentina actual”. Oscar Braun (comp.). El capitalismo argentino en crisis. Buenos Aires: Siglo Veintiuno, 1973, pp. 73-117, p. 85.

${ }^{13}$ Específicamente sobre el PCA en esta coyuntura véase Paola Bonvillani. "Unidad contra la dictadura 'corporativo fascista': algunas lectura del Partido Comunista sobre el golpe de Estado de 1966. Revista Izquierdas. Una mirada histórica desde América Latina, $\mathrm{n}^{\mathbf{0}}$ 22, Instituto de Estudios Avanzados de la Universidad de Santiago de Chile. Santiago de Chile, enero de 2015, pp. 110-132.

${ }^{14}$ La reconstrucción del día a día se realizó a partir de la base construida por Pablo Bonavena. Las luchas estudiantiles en la Argentina. 1966/1976, Secretaría de Ciencia y Técnica de la Universidad de Buenos Aires,
} 
una declaración contra la Ley 16.912 en la que sostenía que “... viene a llenar las aspiraciones del gobierno de someter y amordazar a la universidad para impedir que se cumpla con el pueblo". La misma convocaba a los alumnos a concurrir a las universidades y organizar la resistencia contra la intervención, reclamando la reapertura de las clases con la plena vigencia de la autonomía y la derogación del decreto-ley. Esta declaración fue seguida por los centros estudiantiles y agrupaciones reformistas contrarios a la intervención quienes alertaron sobre el peligro de disolución de estas entidades por parte del régimen.

En ese contexto, en las facultades comenzaron a darse las renuncias docentes. Entre los profesores críticos primó el "renuncismo", la renuncia a los cargos, como modo de manifestar su descontento con una situación que no se pretendía legitimar desde las aulas. Quienes alzaron esta postura, que en Ciencias Exactas y Naturales, Filosofía y Letras y Arquitectura sumó sus mayores adherentes, sobrepasaron a los docentes que preferían "luchar desde adentro" contra el régimen. Más de mil docentes dejaron sus cargos. ${ }^{15}$ Los universitarios comunistas sintieron, al igual que otros tantos, como un desamparo esa situación que los llevaba a quedarse solos frente a los interventores dispuestos por el gobierno. Desde el partido, se llamaba a apoyar pese a todo a los renunciantes con el afán de construir un bloque político que se planteara la recuperación futura de estas casas de estudio. Los jóvenes comunistas impulsaron así un comité junto a graduados y profesores que llegó a editar varios boletines con sus críticas al régimen, poniendo las esperanzas en que la intervención concluyera pronto. Pese a ello, eran escépticos respecto a un apoyo acrítico de un conjunto de dimisiones que juzgaban en el fondo un error. Como la minoría docente crítica que permaneció en las facultades unos meses más hasta que se la expulsó, creían que era mejor que aquellos fueran en el peor de los casos echados que dimitir para deslegitimar a la intervención. Esta cuestión, sin embargo, en el trajín de la lucha no motorizó una polémica abierta con la dirección partidaria. Pero, como se verá, el debate se había suspendido, no cancelado.

En paralelo, se incrementó la represión frente a cualquier manifestación contraria a la intervención universitaria. En estos días la maquinaria represiva estatal hacia la juventud como sujeto peligroso llevada a cabo por el comisario Luis Margaride en Buenos Aires se pondría en marcha. Según Lilia de Riz: "Se persiguió a las parejas en la plazas, se multiplicaron las razias a los hoteles alojamiento, se clausuraron locales nocturnos y se prohibió el uso de minifaldas y pantalones a las mujeres en las escuelas y oficinas públicas. ${ }^{" 16} \mathrm{El}$ mundo de la cultura también resultó afectado al producirse la suspensión de numerosas publicaciones, Tía Vicenta fue la más célebre. Los partidos políticos opositores, el PCA resultó peculiarmente atacado, fueron puestos en la clandestinidad. ${ }^{17}$ Como ha señalado José Luis Romero: "La primera fase del nuevo gobierno se caracterizó por un 'shock autoritario",. 18

Instituto de Investigaciones Gino Germani de la Facultad de Ciencias Sociales de la Universidad de Buenos Aires. Buenos Aires, 1992. Esta base supone un enorme caudal de información diaria para todo el país. En el caso particular de Capital Federal se nutre de los diarios Crónica, Clarín, La Nación y La Prensa. A ello le sumé la lectura de una revista emblemática de la época: Primera Plana.

${ }^{15}$ De acuerdo a Marta Slemenson. Emigración de científicos argentinos: organización de un éxodo a América Latina. Buenos Aires: Instituto Torcuato Di Tella, 1970.

${ }^{16}$ En La política en suspenso 1966-1976. Buenos Aires: Paidós, 2000, p. 53.

17 Sobre la represión al comunismo en estos años véase Jorge Luis Ubertalli. El enemigo rojo. La represión al comunismo en la Argentina. Buenos Aires: Acercándonos Ediciones, 2010, p. 281 y ss.

${ }^{18}$ En Breve Historia Contemporánea de la Argentina. Buenos Aires: Fondo de Cultura Económica, 1994, p. 232. 
Lo sucedido en la Universidad anticipó esta campaña de "moralidad pública" a la vez que expuso su capítulo más brutal. Como ha advertido Mónica Gordillo, las luchas estudiantiles en el país forjaron la principal resistencia al régimen tras el golpe. ${ }^{19}$ Todo un anticipo de ello en la Capital Federal resultó la detención de dos estudiantes en la segunda jornada de agosto de 1966 en cercanías del Hospital de Clínicas por pegar carteles en defensa de la autonomía universitaria, a quienes se les abrieron sumarios por "desorden en la vía pública". Pero además la represión cobró formas más abiertas como lo demostró lo sucedido allí mismo tres días después. Por entonces, un gran número de policías impidió la concentración estudiantil convocada por la FUA frente al Clínicas. Los manifestantes, unos doscientos, debieron improvisar un acto frente a la lindante Facultad de Ciencias Económicas. El mismo concluyó repentinamente ante el avance policial, obligándolos a dispersarse. Tampoco las manifestaciones "relámpagos", es decir acciones de pocas personas que se realizaban sin aviso previo y que tenían una duración acotada pero suficiente para concitar la atención pública con la ruptura del orden que producían, contaron con mejor suerte. Para los jóvenes manifestantes resultó claro que el gobierno no estaba dispuesto a ceder un milímetro de su política universitaria. Si éste debía incrementar la coerción sobre el cuerpo universitario opositor lo haría. En ese sentido, arrancarle demandas al Ejecutivo, o más aún dar por tierra con la intervención, requería un nivel de movilización mucho mayor. No bastaba con el activo militante movilizado.

Las luchas estudiantiles actuarán como si, o pretendiendo que, esta situación sea apenas una circunstancia pasajera. Sin embargo, la represión omnipresente en cualquier protesta que encaraban los estudiantes tendió a desarticular esa presunción. La asunción del interventor de la UBA a mediados del mes, el abogado Luis Botet que se proponía "normalizar" la institución, confirmó la firmeza del gobierno y las dificultades en que se encontraban sus opositores. Ese día, algo ya habitual, resultaron detenidos ocho estudiantes tras las protestas protagonizados por unos setenta de ellos frente al rectorado. Los manifestantes arrojaron volantes de la FUA e Intercentros que decían desconocer a las nuevas autoridades, como así también la aplicación de la ley que establecía el nuevo régimen universitario.

En breve, la dirección comunista fuista en conferencia de prensa anunció que a partir del 22 de agosto se llevarían a cabo asambleas en todas las facultades para analizar los pasos a seguir y decidir la expulsión de las autoridades. Sin embargo, este plan de acción no contó con ningún éxito. Muy por el contrario, el nuevo rector avanzó en su proyecto represivo al disolver los centros de Ciencias Económicas e Ingeniería, conducidos por fuerzas reformistas no comunistas aunque con el apoyo de éstos ante el ataque. Desde el gobierno nacional no sólo se avaló el curso represivo seguido por el rectorado porteño, sino que se dio un nuevo salto en éste al decretar la disolución de la FUA.

Entretanto, tuvo lugar la protesta convocada por dicha federación. En Buenos Aires, se iniciaban ese 22 de agosto las clases en algunas facultades bajo una férrea vigilancia policial. Para ingresar, los alumnos debían mostrar sus pertenencias y la libreta universitaria que los acreditaba como tales a personal de maestranza y policías de civil. No en pocos casos volvían a encontrarse a las fuerzas policiales merodeando pasillos y aulas. En realidad, sólo las Facultades de Agronomía y Veterinaria, Medicina, Odontología y Derecho habían reanudado sus clases. Ingeniería y Farmacia, por su parte, tardarían un tiempo más en lograr la normalización. Mucho más tarde llegaría la

\footnotetext{
19 "Protesta, rebelión y movilización: de la resistencia a la lucha armada, 1955-1976". Daniel James (dir.). Nueva Historia Argentina. Violencia, proscripción y autoritarismo (1955-1976). Tomo IX. Buenos Aires: Sudamericana, 2007, pp. 329-380, p. 344.
} 
paz a Ciencias Económicas. La situación se complicaba particularmente en Ciencias Exactas y Naturales, Filosofía y Letras y Arquitectura, cuyos centros eran dirigidos por los comunistas, facultades en las que corría la idea de que se perdería el año lectivo entre profesores y alumnos. El rectorado porteño, por su parte, al reabrir la Universidad cesanteó a una treintena de estudiantes opositores. En Medicina, pilar de la militancia comunista, las clases comenzarían drásticamente: dos carros de asalto ingresaron al edificio para disolver una asamblea estudiantil que planteaba impedirlo. Los actos, que se repitieron durante toda la jornada, se encontraron con una tenaz respuesta policial que no dudó en abortarlos. Durante esa jornada se evidenció además que los interventores no sólo se valían de las fuerzas del orden y de sanciones legales sino también de otras organizaciones estudiantiles que les respondían. Se trataba de organizaciones de derecha nacionalistas, que reunían un escaso números de seguidores y contaban con una minúscula representación pero que amparadas por la policía mostraban cierto dinamismo. Así, en la calle Paraguay la minúscula Liga de Estudiantes Independientes firmó pintadas censurando a la FUA y a los "bolches". En los carteles que pegaron se leía: "Basta de FUA, desorden, pérdida de clases, política bolche. Nosotros a clase, FUA a Moscú". ${ }^{20}$

Este balance provisorio se iría confirmado con el correr de los días. Ya en la jornada siguiente se empezó a corroborar. La FUA en un comunicado declaró su propósito de "... continuar la resistencia y la lucha por la derogación de la ley 16.912 y en defensa del gobierno tripartito y de la autonomía universitaria, así como por la plena vigencia de los centros de estudiantes." Sin embargo, los hechos pondrán en aprietos el plan de lucha. Ni los estudiantes se movilizaban con la masividad que éste requería para triunfar, ni el resto de los claustros lo acompañó con la fuerza necesaria. Los profesores estaban más compenetrados en decidir destinos para alojar sus equipos de investigación en el exterior que imbuidos en una lucha que consideraban perdida. Por fuera de la Universidad, más allá del PCA eran pocas las formaciones políticas de fuste que brindaban un apoyo cabal a los estudiantes en lucha, a veces por el desorden interno en que se encontraban, otras veces por complicidades, que en buena medida se explicaban por su integración al gobierno. En el mundo del trabajo, junto a quienes los estudiantes en lucha venían protagonizando grandes protestas, un pronunciamiento crítico a la intervención universitaria emitido por las fuerzas obreras comunistas constituyó una excepción dentro de un mayoría sindical peronista que eligió no inmiscuirse en ese tema. $^{21}$

El 14 de septiembre, el deceso del estudiante cordobés Santiago Pampillón, herido de muerte unos días antes por la policía en una protesta, determinó un paro universitario nacional que impactó con fuerza en las UBA. Una "marcha del silencio" coronó la jornada. La conflictividad, trascurrido unos días de este asesinato, poco a poco languideció. Así, "la semana del estudiante en lucha" dispuesta por la FUA para fines de septiembre no pudo romper, pese a que la represión le otorgó cierta difusión al plan de

\footnotetext{
20 "Universidad. Lo que el viento se llevó". Primera Plana, año IV, n 192, 30 de agosto al 5 de septiembre de 1966, pp. 16-17, p. 16.

${ }^{21}$ En el volante, titulado "Los Trabajadores junto a estudiantes y profesores en defensa de la autonomía universitaria", fechado el 30 de agosto, avalado por más de cien firmas pertenecientes a unos veinte gremios, se sostenía: "Los dirigentes y militantes sindicales firmantes expresamos nuestra total solidaridad con la justa y ejemplar lucha de los estudiantes, profesores y graduados en defensa de la autonomía, de gobierno tripartito y de las conquistas culturales del pueblo. La adhesión a esta lucha de repercusión nacional e internacional es un deber inexcusable de todos. Los trabajadores anhelan que la CGT, cumpliendo con ese deber, exprese su solidaridad militante. Así darían también reciprocidad a la activa solidaridad universitaria con las acciones proletarias de los últimos tiempos, donde junto a los mártires obreros cayeron jóvenes estudiantes." (Archivo del PCA)
} 
lucha, la apatía estudiantil. Aunque la dirección comunista universitaria mantuvo a mediados de octubre que la intervención estaba asentada en un "verdadero tembladeral" y agregó que la lucha seguía abriendo nuevas perspectivas, dando cuenta del abigarrado panorama de acciones masivas y nacionales contra ella desde las universidades públicas, este diagnóstico sonaba más a una expresión de deseos que a la realidad. ${ }^{22}$ La monotonía política reinante en el estudiantado iría ratificando el descenso de la conflictividad social y el fin de una etapa. Frente a esta situación una serie de medidas de lucha entraban en suspenso, empezando a plantearse objetivos inmediatos más limitados. Resulta elocuente respecto a la imposibilidad de quebrar la voluntad del gobierno en las calles el hecho de que el Centro de Filosofía y Letras, presidido por los comunistas, ante la reanudación de las clases, sacara un comunicado en el que proclamaba defender "desde adentro lo nuestro", cuando poco antes se empecinaba en impedir el comienzo del ciclo lectivo.

En 1967 la conflictividad social, propulsada históricamente por la conflictividad laboral, mermó notablemente en todo el país. Las protestas universitarias acompañaron esta línea descendente. A comienzos del año, el Centro de Estudiantes de Filosofía y Letras fue disuelto por las autoridades de la facultad. En esta casa de estudios, muchos aventuraban con la posibilidad de que las carreras de Psicología, Sociología y Educación, en pleno desguace, se cerraran definitivamente. El mismo rumor se escuchaba en Arquitectura, llegando la Sociedad de Arquitectos a pedir por la continuidad de la carrera frente al delegado interventor. En Ciencias Exactas y Naturales, según informaba también Primera Plana, las materias de alto nivel de especialización ya no se dictaban. "'Se fueron los mejores', se lamentó un estudiante del doctorado en Física... está estudiando las reglamentaciones aprobadas en el Tratado de Montevideo para ver si es posible rendirla en el Uruguay y jurar allá el título. Como el suyo, hay más de un centenar de casos", completaba la crónica. ${ }^{23}$ Las tres facultades donde los comunistas dirigían sus centros estudiantiles vivían los mayores dramas.

En este contexto, se promulgó finalmente el 21 de abril la "Ley Orgánica de las Universidades Nacionales". La Ley 17.245 contenía cientoveintiseis artículos que regulaban meticulosamente la vida académica. Una rápida mirada no tarda en descubrir la preocupación que transmitía por erradicar la política de las aulas, es decir, una actividad que, según O' Donnell, la dictadura concebía como sinónimo de "desorden", “división de los argentinos" y hasta "subversión". ${ }^{24}$ El especialista en legislación universitaria Emilio Mignone señala que si bien esta legislación planteaba la autonomía académica, el artículo 71 la limitaba. ${ }^{25}$ Asimismo, si bien el artículo 81 otorgaba libertad académica, la cláusula siguiente la restringía al condenar las opiniones políticas. En relación a los estudiantes, la ley reducía el gobierno universitario a los profesores de mayor jerarquía, concediéndoles a los estudiantes voz pero no voto. El representante electo, además, debía ser elegido entre los alumnos del último año y sólo quienes tuvieran aprobada al menos la mitad de la carrera podrían sufragar. La nueva legislación admitía la existencia de centros estudiantiles pero advertía que no podrían realizar ninguna clase de actividad política. Por otro lado, obligaba a tomar exámenes de ingreso a las casas de estudio, previendo que cada facultad encontrara el mejor modo de implementarlos.

\footnotetext{
${ }^{22}$ De acuerdo al folleto de la FUA "Resistencia y Lucha", fechado el 14 de octubre de 1966 (CEDINCI). Respecto a este archivo largamente consultado, cabe aclara que al momento que lo hice su personal se encontraba reestructurando su archivo de volantes. Por lo tanto, no me es posible brindar más información sobre su ubicación puesto que ésta se estaba definiendo por entonces.

23 “Universidad. Un año perdido". Primera Plana, año V, no 210, 3 al 9 de enero de 1967, pp. 23-25, p. 25.

${ }^{24}$ En El Estado Burocrático Autoritario 1966-1973. Triunfos, derrotas y crisis. Buenos Aires: Prometeo, 2009, p. 89.

${ }^{25}$ En Política y Universidad. El Estado legislador. Buenos Aires: Lugar Editorial, 1998, p. 48 y ss.
} 
Frente a esta medida, bautizada más adelante por el estudiantado opositor como "operación ablande", la FUA dispuso una huelga “... en repudio de la nueva ley, por entender que tiene objetivos antipopulares, institucionaliza la eliminación de la estructura democrática en la alta enseñanza y legaliza la persecución del movimiento estudiantil". Pero nuevamente los llamados a la acción no lograron revertir la tendencia descendente de la conflictividad universitaria. Ello motivó que la federación abortara el paro por tiempo indeterminado. A esta altura la dirección comunista ya comenzaba a elaborar una autocrítica de lo actuado. Así lo pone en evidencia un folleto emitido por la Junta Ejecutiva de esta organización en junio de 1967 propuesto para ser discutido en la próxima Convención Nacional de Centros ${ }^{26}$. Respecto a las renuncias de profesores en la UBA, aunque valoraba el que se dieran como parte de una oposición a la dictadura, sostenía ahora abiertamente que tal postura táctica devino en una orientación política equivocada. "Política que tendió, sobrevalorando los alcances de la acción universitaria, a crear las mejores condiciones para una operación de recambio de la dictadura, a concretarse con el apoyo de algún sector del Departamento de Estado norteamericano, y que volviese atrás entre otras cuestiones la nueva estructura universitaria." ${ }^{27}$ Frente a ello se reprochaba no haber combatido esta posición de un modo más firme y público. En este punto se hacía pública una disidencia con el partido ya que desde la dirección del PCA, como se sostuvo, no se planteaba una crítica similar a los renunciantes. ${ }^{28}$ Quizás también otro punto que pueda confirmar una divergencia es la mayor crudeza con que estos jóvenes comunistas juzgaban la actuación de la dirección sindical. Finalmente, se criticaban por haber impulsado "... en algunos centros, hechos políticos que se desligaron de la necesaria construcción del proceso estudiantil masivo que junto a la clase obrera y el pueblo, y sólo así, podrá hacer variar radicalmente la situación..." lo que conllevó a "una acción que visualizó el hecho de resonante efecto y no la construcción del proceso." 29

En un clima fuertemente represivo, el nuevo elenco universitario había impuesto una derrota a la militancia estudiantil opositora de la que no podía recuperarse. Los comunistas, que como mostró esta síntesis de este primer año de intervención universitaria ocupaban posiciones dirigentes en este proceso, se encontraban en el centro del drama universitario que llevaba a poner en debate el modo en que habían conducido la lucha. En este marco, los resquemores hacia la dirección de su partido salieron a la luz con mayor virulencia, impulsando la ruptura.

\section{Los documentos de la ruptura}

\footnotetext{
26 "FUA" Informe que se elevaba para ser discutido en la Convención Nacional de Centros motorizada por la federación (CEDINCI).

27 "FUA", p. 24.

${ }^{28}$ Una nota aparecida en una revista del PCA a fines de 1966, en la que se hacía un balance de la política comunista en la Universidad tras la intervención, señalaba que aunque auspiciaban otras medidas de lucha, como la de los profesores que se quedaron para ofrecer resistencia, no dejaron de estimar a quienes renunciaron. La nota agregaba que lucharon desde el comienzo para que se hiciera una falsa división entre renunciantes y no renunciantes. El tono más benévolo y comprensivo de la nota, era el tono que el partido promovía hacia los renunciantes. Nota firmada por Bernardo Kleiner, Berta Perelstein y Sergio Rodríguez. "Universidad y dictadura". Nueva Era. Revista Teórico-política del Partido Comunista de la Argentina, no 11, diciembre de 1966, pp. 58-70, p. 6.
}

29 "FUA", p. 26. 
Nadie que leyera sin estar imbuido en la vida cotidiana del PCA sus principales publicaciones podría sospechar sobre la ruptura motorizada por un sector relevante de la juventud que se haría pública en septiembre de 1967. Efectivamente, las páginas partidarias, respondiendo a una tradición partidaria, poco advertían sobre los cuestionamientos que conducirían a dicho divorcio. Nuestra Palabra, el semanario del PCA, no sugería nada en los meses previos de la ruptura que pueda preanunciarla. A principios de junio comunicaba sobre la VII Conferencia convocada recientemente por la FJC, no dejando trascender absolutamente nada sobre debates internos. ${ }^{30}$ Es más, en el número de mediados del mes siguiente, en las páginas que se explayaba sobre la evolución de la campaña financiera en marcha se felicitaba especialmente a la juventud universitaria de la Capital Federal por haber alcanzado el primer millón. ${ }^{31}$ Estos elogios ya se habían realizado en Nueva Era, la revista oficial del partido, en uno de sus primeros números de 1967. La crónica de lo sucedido en la Capital Federal, epicentro de la inminente escisión, sostenía: “... las organizaciones de la Juventud Comunista aplicaron certeramente la línea del partido y desempeñaron el papel decisivo al saber trabajar por la unidad de los distintos sectores del estudiantado y unir sus fuerzas al conjunto de las de la Universidad." 32 En el número siguiente, dedicado a la VII Conferencia del PCA, el secretario general de la FJC, Héctor Santarén, hombre sumamente orgánico al partido, señalaba debilidades de la FJC en el terreno organizativo, como el hecho de que el reclutamiento en el marco de conflictos haya sido bajo últimamente, pero dejaba bien en claro la adhesión incondicional de este sector al PCA. Los números de junio y julio siguientes recogían diferentes opiniones en las que se reflexionaba sobre la situación universitaria, entre las que había voces de los universitarios que se marcharían, aunque no sugerirían ninguna rivalidad partidaria. Es llamativo asimismo que en Juventud, órgano oficial de la FJC, no se registraran abiertamente polémicas con el partido. Pero, más allá de que esto sea así, lo importante es destacar que nunca hasta los inicios de la ruptura se polemizó abiertamente con la dirección del PCA. Esto es más llamativo si se tiene en cuenta que los que se fueron finalmente venían manejando esta publicación. Del mismo modo Línea, periódico de los estudiantes universitarios comunistas, también controlado por quienes motorizarían la ruptura, lejos de esbozar críticas al partido, recurría a las actitudes reverenciales características de su relación pública con el mismo. ${ }^{33}$

Cuadernos de Cultura, la revista que el PCA dirigía a los intelectuales, resultó una excepción al dejar entrever polémicas entre la juventud y la dirección partidaria. Desde siempre esta publicación había reflexionado largamente sobre la cuestión universitaria. Inmediatamente después del golpe de Estado de 1966, Sergio Rodríguez, encargado del sector estudiantil de los universitarios comunistas en la Capital Federal, escribió un artículo en el que analizaba la nueva situación. ${ }^{34}$ Con optimismo, el texto redactado unos días antes de la intervención hacía hincapié en la actitud decisiva del partido a la hora de ganar a las masas universitarias. En el número siguiente, una vez consumada la

\footnotetext{
30 "Se realizó la VII Conferencia de la Federación Juvenil Comunista". Nuestra Palabra. Órgano del Partido Comunista, no 883, 6 de junio de 1967, p. 4.

31 "Para el recuadro de honor de la juventud". Nuestra Palabra, no 889, 18 de julio de 1967, p. 6.

32 "Los comunistas en las luchas de la Capital". Nueva Era, año XVIII, no 2 (144), marzo-abril de 1967, pp. 62-75, p. 67. El artículo fue firmado por Athos Fava, militante mayor que permanecería en el partido.

${ }^{33} \mathrm{Al}$ respecto Línea. Periódico de los estudiantes universitarios comunistas, año 6, n 25, 17 de abril de 1967. Este es el último periódico que me fue posible consultar antes del editado en septiembre que ya se repasará. Lamentablemente, el $\mathrm{n}^{\circ}$ 26, que está en el medio de ambos, me ha sido imposible de encontrar.

34 "Perspectivas del estudiante universitario". Cuadernos de Cultura, n 81, julio-agosto de 1966, pp. 37 46.
} 
intervención, Giúdici aportó una extensa reflexión a modo de balance en la que además fundamentaba la política universitaria por seguir. ${ }^{35} \mathrm{Su}$ palabra, más que cualquier otra, resultaba central ya que este intelectual era el principal dirigente del PCA encargado hace una década de ayudar a los jóvenes en la elaboración y aplicación de la línea partidaria en la Universidad. En esta nueva reflexión, lanzaba una advertencia respecto a lo dicho por el anterior:

Pretender, como hace S.R... que pasar de los objetivos específicos de la Universidad a la unidad obrero-estudiantil revolucionaria es un progreso, implica caer en un serio error. Este cambio se encaró, teóricamente, hace más de treinta años en el movimiento reformista, y desde entonces el ascenso consistió en integrar lo revolucionario general y lo específico, con el desarrollo de esto último como deber responsable del movimiento reformista. Toda nueva disociación y mutilación es un retroceso. Deja de comprenderse entonces que es lo que cambia en la Universidad y cuál es la fuerza nueva que desde ésta se incorpora al país; no se comprende, por ello, desde una base económica, la fuerza ideológica que pasa a ser relativamente primera y decisiva en ese campo específico de la educación y la cultura. Sin ello, naufragan las más sanas intenciones revolucionarias. ${ }^{36}$

La crítica apuntaba, en definitiva, a no reducir el análisis universitario a lo clasista enunciado de un modo genérico, esto es, como puro economicismo puesto que ello hacía perder de vista la única perspectiva desde la que era plausible abordar la lucha de clases: la que partía de lo específico en la Universidad. En segundo lugar, el artículo realizaba un constante llamado de atención al hecho de mantener la alianza con la nueva fuerza social científica que conformaban muchos profesores renunciantes, dimisiones que por otro lado saludaba dado el golpe que le infligieron a la dictadura. En ese sentido, criticaba a quienes no las valoraban como él. Finalmente, el autor sugería no perder de lado la integración total de la línea política, no descuidando el plano ideológico en pos de un inconducente llamado a la revolución, lo cual los acercaría a la "ultrazquierda", un sector siempre criticado por su "revolucionarismo" inoperante. El artículo concluía sosteniendo: "Queda una línea: científica y política. En la ciencia, otra política; en la política, más ciencia."

A comienzos de 1967, Leonardo Paso, el máximo responsable partidario de la Capital Federal, opinaba sobre la actualidad universitaria. ${ }^{38}$ Bajo un retroceso marcado de la conflictividad social, no imperaba en estas páginas el optimismo que había surcado la reflexión de Giúdici. Al final del texto advertía que "hay quienes andan confundidos o quieren confundir cuando nuestro partido lanza la consigna de recuperar esa universidad. No cabe dudas de qué es lo que defendemos." ¿A quién le hablaba Paso? ¿Sólo a los extrapartidarios? ¿O intuía que había correligionarios no muy

\footnotetext{
35 “QQué ha sucedido en la Universidad Argentina?”. Cuadernos de Cultura, nº 82, septiembre-octubre de 1966, pp. 9-46.

36 “¿Qué ha sucedido en...”, p. 10.

37 “QQué ha sucedido en...”, p. 46.

38 "Proyecciones y limitaciones en la Lucha Universitaria". Cuadernos de Cultura, no 84, marzo-abril de 1967, pp. 34-50.
} 
convencidos de la línea del PCA? Es imposible saberlo. Pero si esas palabras planteaban tal divergencia interna, como sin dejar dudas lo había hecho Giúdici unos meses antes, nada haría razonar que ambos disensos conducirían inevitablemente a una fractura.

En el número siguiente se publicó un artículo firmado por Sergio Rodríguez y Oscar Landi, otro importante dirigente universitario (presidente del Centro de la Facultad de Filosofía y Letras de la UBA). ${ }^{39}$ En éste se leía:

A veces en el apasionamiento de la discusión contra las posiciones de la ultraizquierda -que propugna el abandono de la lucha en la universidad- se argumenta que al imperialismo se lo combate desde cada trinchera social (los estudiantes en la universidad, los obreros en la fábrica, los campesinos en el campo, etc.). Esto es cierto, pero parcialmente, pues si esas batallas no son orientadas a vincular cada sector al resto en la perspectiva del asalto al poder, se transforman en batallas defensivas que no tienen más perspectivas que las de lograr mejoras parciales, pero siempre dentro del mismo régimen y con el peligro de perderlas en cualquier momento, como hoy ocurre en la universidad. ${ }^{40}$

Las críticas, sin menciones directas a nadie, indudablemente se dirigían a la dirección del partido. En estas líneas se reclamaba un mayor protagonismo en la lucha de clases de parte de los estudiantes, poniendo en el centro la cuestión del poder. Constituía una interpelación directa a planteos partidarios que en su afán de que los estudiantes se ocuparán de la especificidad del sujeto que debían movilizar en la Universidad, los relegaban de las principales decisiones políticas. Si ello era cierto o no, o en qué medida podía considerarse de ese modo, no es lo que importa aquí. Es suficiente advertir que desde la perspectiva de los estudiantes críticos resultaba así. Sin embargo, de estas críticas, al igual que sucedía con las críticas de los dirigentes partidarios, no podía colegirse una ruptura inminente. Es verdad que el PCA se había caracterizado siempre por su monolítica disciplina: lo que decía la dirección no se cuestionaba, se acataba. Con todo, las señales que estas contadas controversias públicas daban de un proceso a punto de estallar eran, a lo sumo, insuficientes.

De acuerdo a lo repasado, pues, se hace evidente que si las intenciones de romper con la organización existían de parte de la mayoría de la FJC, éstas no habían salido a la superficie. ¿O en realidad hasta entonces no se pensaba en marcharse, sino en cambiar desde adentro al partido? ¿Fue entonces la propia tozudez del PCA de renovarse lo que provocó la partida juvenil? Como siempre sucede, las versiones dan la razón a quien las enuncia. Como se verá, ambos contendientes dieron cuenta, al momento de la ruptura, de malestares que subrepticiamente se acarreaban hace rato.

Un primer anuncio de las divergencias internas se hizo público en septiembre de 1967 a través de Juventud y Línea. ${ }^{41}$ Sus páginas se dedicaban a trascribir íntegramente

\footnotetext{
39 "Los estudiantes comunistas y las perspectivas de la Universidad". Cuadernos de Cultura, nueva época, $n^{\circ} 1$ (85), septiembre-octubre de 1967, pp. 89-99. Nótese que este número fue publicado con posterioridad al inicio de la ruptura. Es posible trazar tres conjeturas sobre ello: los editores pese a todo decidieron publicar el número, éste ya estaba preparado y no quedó otra que sacarlo o, finalmente, los editores imprimieron la revista poco antes o sin percatarse aún de la escisión.

40 "Los estudiantes comunistas y...", p. 96.

${ }^{41}$ Línea. Periódico de los estudiantes universitarios comunistas, septiembre de 1967, año 6, no 27 y Juventud. Órgano de la Federación Juvenil Comunista, edición extra, septiembre de 1967. En las citas
} 
lo resuelto por el Comité Ejecutivo (C.E.) de la FJC en su reunión del 18 de septiembre. $^{42}$ Durante las últimas semanas, se narraba, se habían planteado preocupaciones en torno a cómo fortalecer política y orgánicamente la organización por parte de compañeros de este CE pero también de los comités locales de la Capital, de Santa Fe, de Mendoza, así como en los sectores y organismos universitarios de todo el país (Buenos Aires, La Plata, Rosario, entre otros) y en las comisiones colaboradoras nacionales y provinciales (Comisión Sindical de Relaciones Políticas, por ejemplo). Se sostenía que el C.E. votó por mayoría abrir el debate ante un miembro del Secretariado Nacional del PCA, que luego no reconoció este hecho, prefiriendo la tergiversación. Se agregaba:

Ante la situación creada, miembros del secretariado nacional de la FJC, preocupados por el no funcionamiento del C.E. -se suspendieron reuniones programadas- lo que dificulta analizar el conjunto de los problemas surgidos y discutir la realización próxima de un CC [Comité Central] (ya convocado por el CE anteriormente) propusieron su urgente funcionamiento. Esto no fue aceptado por tres miembros del secretariado, entre ellos el secretario nacional de la FJC. Frente a esta situación, la mayoría del CE decidió autoconvocarse. La reunión se realizó con la presencia de seis de sus miembros: los responsables nacionales obreros y universitarios, los responsables del trabajo de masas y con las juventudes políticas y la Coordinadora, y los secretarios de la FJC de la Capital y Santa Fe.

En ella se aprobó la presente resolución, el enviar una carta a nuestro Partido y la citación del próximo CC. Asimismo, enviar delegaciones al conjunto de las regiones a discutir la presente situación. ${ }^{43}$

En el CC de la FJC, reunido el 21 de septiembre, sus quince miembros asistentes resolvieron por unanimidad aprobar el informe del $\mathrm{CE}$, encargar a éste un documento político de fondo sobre la actual situación, citar al IX congreso de la FJC, repudiar a los que niegan el debate, solicitar una reunión con el CE del PC para encontrar los medios que mejor resuelvan la situación.

Los cuestionamientos políticos que habían llevado a esta situación partían de la preocupación acerca de la pasividad de las masas, ya que las mismas no ganaron las calles como el PCA había previsto. Los cuestionamientos al partido se dirigían a tres áreas centralmente: la crítica a una orientación no suficientemente clasista en el plano sindical, la falta en el plano político más general del mantenimiento de la independencia política e ideológica en las eventuales alianzas que se tejían con otras fuerzas y,

posteriores la numeración se refiere a ambas revistas, ya que las dos se dedicaron a emitir dicho comunicado.

${ }^{42}$ Otto Vargas, quien se convertiría en líder de los rupturistas, sostuvo que esta determinación fue producto de un ataque inicial por parte de la dirección del PCA. Según éste, frente a la rebelión de la FJC "En determinado momento, cuando esta fuerza crecía, para romperla y contenerla, la dirección del PC, fragua una denuncia por trabajo fraccional contra una camarada, e inicia la intervención de la FJC en la Capital, y a las direcciones barriales de ésta. Así provocan ellos la ruptura." Véase Jorge Brega. ¿Ha muerto el comunismo? El maoísmo en la Argentina. Entrevista con Otto Vargas. Buenos Aires: Ediciones Brega, 2012, p. 36.

43 “Línea..." y "Juventud...", p. 4. 
finalmente, en el contexto latinoamericano las carencias en la aplicación de la línea ofensiva en relación a la Organización Latinoamericana de Solidaridad (OLAS), impulsada por Cuba y su estrategia revolucionaria armada, a la que el PCA veía con renuencia. Pese a todo, el periódico concluía con vivas al partido y a la FJC.

Un documento de 42 páginas firmado por el CC de la FJC en el mes de octubre siguiente se explayaba largamente sobre los cuestionamientos a la política seguida por el PCA fechado en octubre de $1967 .{ }^{44}$ En primer lugar, se fustigaba la caracterización realizada en la VII Conferencia Nacional, realizada en abril de 1967, respecto al derrocado gobierno de Illia en la que se había concluido que bajo la presión popular, apoyando sus medidas progresivas, se habría logrado la reorganización gubernamental, satisfaciendo de este modo las demandas populares. Para estos jóvenes, por el contrario, "El no haber denunciado y atacado suficientemente la política, en lo esencial reaccionaria del gobierno de Illia, facilitó a la derecha peronista su maniobra de aparecer como los más decididos combatientes de esa política, lo que era un pretexto para enganchar a las masas detrás del golpe." ${ }^{45}$ En relación al sindicalismo peronista, poniendo el acento en su principal dirigente, el metalúrgico Vandor, se sostenía que en el afán de conquistar la unidad del movimiento obrero se apaciguaron las ineludibles críticas a "la actividad criminal y reaccionaria de estos elementos sindicales, actitud que a nuestro entender, no ayudo a la clase obrera y al pueblo a ver los verdaderos propósitos de estos dirigentes y mostrar cómo, tras una aparente política unitaria y de oposición 'frontal' al gobierno de Illia, se ocultaban sus fines golpistas." ${ }^{46}$ Este error, se denunciaba, persistía al no rechazarse claramente el anticomunismo reinante en esta dirección sindical que se buscaba seducir. Se reclamaba, en ese sentido, mayor protagonismo al partido.

El texto no sólo atacaba la línea política del partido durante los últimos años, sino que también se defendía de las críticas que ya había recibido por parte de su conducción. En primer lugar recusaba la caracterización hecha en la referida reunión del CC oficialista de la FJC que los acusó de pregonar un aventurerismo sectario que los aislaba de las masas juveniles. Para contrarrestar este planteo, se relataban los avances que habían alcanzado en el movimiento obrero. Respecto a la crítica de que ellos habían olvidado las reivindicaciones juveniles, respondían aseverando su falsedad como lo probaba la lucha que llevaban adelante en la Universidad por más presupuesto. Esgrimían además, retomando un discurso que ya se ha comentado, que pese a que había que luchar por estas reivindicaciones no había que acotar la lucha a ellas, ya que hacerlo implicaría caer en el apoliticismo.

De cara a la salida de la situación actual que se avizoraba desde el PCA, estos jóvenes volvían a criticar el documento de la VII Conferencia. Lanzaban: "No entendemos porque en ninguna de estas citas se expresa la necesidad de la toma del poder por la clase obrera y el pueblo, para la realización de estos cambios..."." Sostenían que no precisar las clases que definirían los cambios en las consignas partidarias generaba confusiones que llevaban al espontaneísmo. Todo ello redundaba

\footnotetext{
44 "Hacia el IX ${ }^{\circ}$ Congreso. Por la unidad y la defensa de la FJC y el PC sobre la base de los principios leninistas", octubre de 1967, firmado por el CC de la FJC (consultado en el Archivo del PCA pero también disponible en el CEDINCI). Este texto también se encuentra en una compilación de documentos intitulada Documentos del PCR. Desde la ruptura con el PC revisionista hasta el Primer Congreso del PCR realizado del 11 al 14 de diciembre de 1969. Tomo 1. Buenos Aires: Edición del Partido Comunista Revolucionario (PCR), 2002.

45 “Hacia el IX ${ }^{\circ}$ Congreso...,", p. 2.

46 "Hacia el IX ${ }^{\circ}$ Congreso...,", p. 3.

47 "Hacia el IX Congreso...", p. 13.
} 
en seguir detrás de las masas y no conducirlas en la lucha por el poder, que era la tarea de vanguardia que debía asumir el partido. Por otro lado, frente a la amenaza de un golpe de Estado llamaban a movilizar más activamente a las masas en su contra. Un señalamiento especial merecía la alerta de no subestimar la preparación militar, la cual por el contrario había que mejorar.

En definitiva, como se observa, si hay un denominador común del malestar entre los jóvenes disidentes es el reclamo de una actitud política más aguerrida a la dirección del PCA. En momentos en que la conflictividad social en el país era baja (también en la Universidad, donde tenían su epicentro), mostrándose el régimen todopoderoso, se hacía evidente para los disidentes la falta de protagonismo del partido en la política nacional. En paralelo, se reclamaba mayor atención a los planteos de esta juventud, voz a la que urgía otorgarle un lugar más destacado en las principales decisiones. El documento concluía, al igual que lo habían hecho a través de Línea, afirmando su voluntad de permanecer en el partido, pero al mismo tiempo reclamaba que se abriera el debate. ¿Este planteo de unidad era sincero? ¿O, más bien, los disidentes sabían que era imposible que la dirección convocara al diálogo pero juzgaban, en el juego político, necesario exigirlo?

Si es que había alguna chance de evitar la ruptura definitiva, el accionar de la dirección del PCA terminó por acabar con cualquier posibilidad de que los disidentes permanecieran en sus filas. Desde el partido se encargaron de desacreditarlos y expulsar a sus principales figuras, y sólo intentaron afianzar sus vínculos con aquellos que habían quedado a la deriva, no sabiendo por quién optar. A comienzos de octubre Nuestra Palabra ofreció una versión contrapuesta a la plasmada por los disidentes acerca de las circunstancias en que se gestó la ruptura. Una declaración firmada por el CC de la FJC, que reflejaba lo dispuesto en la reunión del 26 de septiembre, informaba que a este encuentro fueron invitados todos sus miembros pero hubo quienes no concurrieron ya que sus planes eran crear un sedicente "movimiento juvenil revolucionario". ${ }^{48}$ Frente a este grupo "fraccionista y antipartido" este CC había resuelto separarlos y nombrar una comisión investigadora. Entre los expulsados figuraba Jorge Rocha, presidente de la FUA. Se acusaba a los echados de pretender hacer su propia política, usando para ello los órganos directivos y de prensa de la FJC, disimulados sus argumentos con preocupaciones y dudas sobre la línea oficial. Lo que se pretendía, pues, era sabotear la política del partido, apelando al sectarismo y aventurerismo. Se comprobaba, por ejemplo, que entre las juventudes, y sobre todo en el movimiento obrero, los avances habrían sido mayores de no ser por este grupo "antipartido" y su "doblez". Otra de las acusaciones que se vertía sobre éstos era la de "pseudo revolucionarios pequeño burgueses".

Lo "pequeño burgués" se constituiría en la clave explicativa del porqué de la ruptura. En los meses siguiente Nuestra Palabra dedicó una serie de notas en las que, sin mencionar a los disidentes, quizás como un modo de no darle mayor dimensión a su partida, se defendía no obstante la política del PCA en los aspectos que habían sido criticados por éstos. Así, por ejemplo, se aclaraba que el partido siempre tuvo una línea de clase independiente o en relación a la clase obrera se señalaba que no se tenía que apartar de ésta a quienes debían ser sus aliados. En el medio de estas notas, a comienzos de noviembre, al reflexionar sobre una ruptura juvenil que había sufrido hace un par de años el PC francés se sostenía que "Los tales grupos pequeño-burgueses actúan principalmente en el ámbito universitario, tratando de sacar provecho de los rasgos

48 "Declaración del Comité Central de la Federación Juvenil Comunista". Nuestra Palabra, nº 900, 3 de octubre, p. 5. 
universitarios que los distinguen." 49 Se concluía que: "No asombra entonces que también acá la influencia burguesa elija igualmente la esfera universitaria para tratar de introducir su veneno ideológico. El anticomunismo y el fraccionalismo son la avanzadilla de la ideología nacionalista burguesa." ${ }^{, 0}$

La peculiaridad de la extracción social para entender la ruptura aparecería mejor explicada en el último número de 1967 de Cuadernos de Cultura. ${ }^{51}$ La extracción universitaria, permitía explicar sociológicamente la escisión ya que esta ubicación estructural los hacía propensos a vacilaciones ideológicas y a la impaciencia política. Aunque entre éstos había dudas juveniles sinceras, el modo en que había procedido, intentando enfrentar a la FJC con el PC, le quitaba toda legitimidad a su accionar. En relación al programa del PCA que los "fraccionistas" habían puesto en cuestión, el núcleo de la respuesta pasaba por señalar la incomprensión de la situación política que los llevaba al sectarismo y, como resultado, al aislamiento. Se rompía así, argüían, la posibilidad de coincidir con aquellos que luchaban contra la dictadura pero que no aceptaban en todo el programa del PCA ya que no se distinguía entre el enemigo principal (el imperialismo, la oligarquía y el gran capital intermediario) y las distintas clases y capas sociales susceptibles de integrar el frente democrático nacional. Esta tesis "trotskista", se agregaba, llevaba al asilamiento al cederles las masas que no se disputaban al enemigo. Se daba como ejemplo lo que sucedía actualmente en la Facultad de Medicina de Buenos, recuérdese, el bastión de los comunistas en la Universidad. Allí se postergaba ruinosamente la batalla específica hasta tanto no se produzca la unidad del programa revolucionario y la toma del poder, lo que llevaba al asilamiento de la vanguardia. En definitiva, se rechazaba la consigna "gobierno de amplia coalición democrática" que levantaba el PCA al considerarla estos jóvenes contraria al "poder obrero y popular". Esta impaciencia política también se observaba en la crítica al partido de no haber conquistado la hegemonía en el movimiento obrero. La crítica en este punto no recaía tanto en la necesidad de esa búsqueda, que efectivamente constituía un déficit más o menos asumido, sino en el hecho de no darse por ello una política frente a otros sectores hasta que no se triunfara en la clase obrera. Así: "En el ámbito cultural -y en particular en el universitario- queda sepultada la lucha por insuflar un contenido actual a la propia Reforma Universitaria y se esteriliza toda posibilidad contemporánea de alianzas con sectores tales como las masas influidas por el humanismo y otros sectores igualmente vastos y ponderales de la vida cultural."

Entre el 4 y 5 de noviembre de 1967, se reunió la Comisión Nacional Universitaria del PCA. ${ }^{52}$ El informe de Giúdici aquí expuesto puso de relieve que el extremismo de ultraizquierda y la reacción terminaban identificándose. "Trasladar a ésta un esquema clasista puro, sin tener en cuenta a los aliados y las etapas intermedias, significa, simplemente, liquidar a cualquier movimiento de masas." 53 La línea sectario oportunista que se había aplicado en la juventud había conducido a "... un debilitamiento de organizaciones estudiantiles, centros y federaciones regionales,

\footnotetext{
49 “Influencia de la ideología burguesa". Nuestra Palabra, no 905, 7 de noviembre, p. 2.

50 "Influencia de la...," p. 2.

51 “A propósito de una plataforma fraccional entre los jóvenes". Cuadernos de Cultura, Nueva Época, noviembre-diciembre de 1967, $\mathrm{n}^{\circ} 2$ (86), pp. 129-134. Aunque en el índice de la revista el artículo se encuentra firmado con las iniciales B.L., que no pude identificar, cuando comienza no hay quien lo suscriba.

${ }^{52}$ La Línea de los Comunistas en la Universidad. Folleto editado como Suplemento de la revista Línea, noviembre de 1967 (consultado en Archivo del PCA aunque también se encuentra en el CEDINCI). Ya para entonces esta revista, al igual que Juventud, había vuelto a ser controlada por el PCA.

53 “La Línea de los Comunistas...,", p. 5.
} 
reduciendo la lucha de masas a núcleos activistas que buscan el éxito en hechos políticos directos..." ". Esta política "exitista" desligada de las masas “... ha despreciado la lucha específica, ideológica, en la Universidad, pretendiendo encontrar un reflejo mecánico de la lucha de clases en la misma...".55

Respecto a esta última cuestión, es llamativo que tal autocrítica aludiera con tal dureza al presente universitario ya que, como he mostrado en el apartado anterior de este artículo, desde las propias filas fuistas la dirección estudiantil cuando aún permanecía en el PCA venía autocriticándose desde mediados de 1967 por su accionar. Esta autocrítica, por cierto, una vez que estos jóvenes rompan con el partido, se seguiría sosteniendo. ${ }^{56}$ En un contexto de derrota marcado por la baja conflictividad universitaria, desde el partido se planteaba como gestores de esta situación a quienes debían haber aplicado la línea del partido por no haberla desarrollado adecuada o directamente por haberla rechazado en la práctica. Dado que no había nada de que reprocharse entonces, quizás tan sólo la insuficiente vigilancia revolucionaria ejercida de cara a los "faccionistas", era lógico depositar todas las culpas entre sus contendientes. Más allá de las interpretaciones plausibles de hacer sobre la corrección o no de esta actitud, es evidente que entrababa en abierta contradicción con las felicitaciones de meses antes con que desde los principales órganos de prensa, de las que se dejó registro más arriba, se había distinguido a estos militantes universitarios.

Las caracterizaciones del PCA fueron respondidas por los disidentes. Otto Vargas, su máximo líder, cuatro meses después de iniciada la ruptura realizó una pormenorizada crítica al partido. ${ }^{57}$ En primer lugar, manifestaba que desde el mismo se había impedido todo tipo de discusión con el CC de la FJC. Recusaba, asimismo, las críticas que aludían al carácter exclusivamente estudiantil de los disidentes. Desde su punto de vista la ruptura incluía también sectores de trabajadores, pero incluso aceptando que los universitarios eran mayoría, eso no debía invalidar sus críticas ni la necesidad de responderles. En ese sentido, subrayaba que desde Nuestra Palabra se tergiversaban sus opiniones críticas para no responder lo que se debía responder. El núcleo de la argumentación de Vargas pasaba por considerar:

... que los errores señalados son manifestaciones de una deformación oportunista que, si bien no cree capacitada a la burguesía nacional para dirigir y realizar las transformaciones revolucionarias agrarias y antiimperialistas, cree, por diversas razones, QUE SÓLO ESA BURGUESÍA SERÁ CAPAZ DE INICIAR EL PROCESO REVOLUCIONARIO EN EL PAÍS. ${ }^{58}$

Esta postura expectante respecto a determinadas fracciones burguesas, se agregaba, llevaba a darle tanto al partido como a la clase obrera un rol secundario. Esta estrategia respondía a una idea "indolora" del proceso revolucionaria que respondía a una concepción pacífica del mismo. Más allá de repetir críticas que ya se han analizado, el

\footnotetext{
54 “La Línea de los Comunistas...”, p. 9

55 "La Línea de los Comunistas...", p. 10.

${ }^{56}$ La FUA repitió tal cual la autocrítica de mediados de año en su congreso de fines de 1967. Véase al respecto Carlos Ceballos. Los estudiantes universitarios y la política (1955-1970). Buenos Aires: CEAL, 1985, p. 120.

57 “¿Por qué no se quiere discutir?”. Artículo enviado a la revista Nueva Era finalmente rechazado y publicado como folleto por el del C.C. de la F.J.C durante diciembre de 1967 (CEDINCI). También se puede leer en Documentos del PCR. Desde la ruptura...

58 “¿Por qué no se...”, p. 10.
} 
texto concluía llamando a liquidar las tendencias "sectarios-oportunistas" en el partido, rompiendo así con todo puente.

Poco después, a comienzos de 1968, se constituiría el Partido Comunista Comité Nacional de Recuperación Revolucionaria. En la declaración fundacional se asumían las responsabilidades que le competían en la crisis partidaria, cuestión que se decía los diferenciaba de la dirección comunista, como un punto de partida radical que los encamine hacia la verdadera senda clasista y revolucionaria. ${ }^{59}$ Tras repetir el balance ya expuesto, en el documento se sostenía:

\section{ASUMIMOS ANTE EL CONJUNTO DE LOS MILITANTES DEL PARTIDO COMUNISTA, DE LA CLASE OBRERA Y EL PUEBLO,CON EL FIN DE SALVAR AL PARTIDO PARA LA REVOLUCIÓN LA RESPONSABILIDAD HISTÓRICA DE RECONSTRUIR LA LÍNEA Y DE REESTABLECER LOS MÉTODOS LENINISTAS. Para ello organismo y militantes del P.C. de la Pcia. De Buenos Aires, la Capital Federal, Santa Fe, Tucumán, Mendoza, Córdoba y Corrientes, reunidos el día 5 de enero de 1968 en un lugar de la Pcia. de Buenos Aires, nos constituimos en COMITÉ NACIONAL DE RECUPERACIÓN REVOLUCIONARIA DEL PARTIDO COMUNISTA DE LA ARGENTINA. ${ }^{60}$}

No obstante, advertía que si se levantaban las antiestatutarias expulsiones y sanciones, se repusiera a todos los camaradas en sus puestos, se abriera la discusión orgánica, se habilitara los órganos de prensa para desarrollar el debate y se respetara finalmente la rectitud de la vigencia del PCA, este comité se disolvería.

Un folleto contemporáneo a los anteriores documentos de más de sesenta página editado por la FJC dejó en claro que desde la dirección del PCA no se aventuraba ninguna reconciliación. ${ }^{61} \mathrm{El}$ mismo incluía el informe de la comisión investigadora acerca de la ruptura en el que se confirmaba la expulsión de los dirigentes disidentes Jorge Rocha, Carlos Echague, Manuel Campos y Ricardo Rubinich. El texto comunicaba que en la reunión del supuesto "CC" de la FJC, la de una semana antes que la que hicieron ellos, habían participado apenas nueve titulares sobre veintiseis, por lo que debieron ascender seis suplentes para funcionar. Se habían adoptado así ilegítimas resoluciones en nombre del verdadero CC. En relación a los fundamentos de la separación el folleto trascribía el informe de Héctor Santarén rendido ante el CC de la FJC en su reunión del 21 de diciembre de 1967 (encuentro que siguió al de septiembre). En el mismo se repetían las acusaciones al "grupo fraccionista" de llevar a cabo una acción "sectaria, aventurera y antipartidaria". Además, se refería a éstos como un "grupúsculo de intelectuales y estudiantes de extracción pequeñoburguesa". Para reflejar lo que se pensaba en el

\footnotetext{
${ }^{59}$ Esta acta fundacional fue reproducida íntegramente por el nuevo periódico de esta organización. Véase Nueva Hora. Órgano del Partido Comunista Comité Nacional de Recuperación Revolucionaria, quincenal, año $1, \mathrm{n}^{\circ} 1$. Buenos Aires, 12 de febrero de 1968. Se puede encontrar asimismo en Documentos del PCR. Desde la ruptura...

60 "Nueva Hora...", p. 41.

61 “Asimilar, difundir y defender la línea del Partido para unir y coordinar las luchas de la juventud por sus derechos y contra la dictadura" Buenos Aires: Ediciones Voz Juvenil (Archivo PCA). No está fechado pero dado que los acontecimientos que se narran son de fines de 1967, creo que a lo sumo salió a luz a comienzo de 1968.
} 
terreno práctico respecto a aquellos se sostenía que los sectores fraccionistas respecto a Vietnam dicen que lo mejor que se puede hacer por ellos es hacer la revolución en nuestro país, lo cual es cierto, pero que mientras tanto no hacen nada. Es decir, se los acusaba de disimular detrás de sus ideas revolucionarias su carencia política ante las grandes masas.

En el apartado referido a las Universidad las críticas recaían con mayor dureza aún. Se sostenía que la línea sectario oportunista fue impulsada principalmente por la Comisión Universitaria de la FJC y en particular por las direcciones de los sectores de la Capital Federal, La Plata y Rosario, aunque por todos los medios intentaron llevarla al resto del país. Resumiendo, se los acusaba de sabotear la línea del partido, pasarse a la ultraizquierda y no atender las cuestiones específicas de la Universidad, realizando el trasplante mecanicista de la lucha de clases a este ámbito. Respecto al Congreso de la FUA de fines de 1967, realizado en condiciones de semiclandestinidad, se recusaba a los organizadores de no haber realizado un congreso representativo de masas sino una reunión de tendencias. Así: "De 250 delegados que debía tener el congreso, no llegaron a participar 150. Y lo que es más serio, electos por menos de 1.500 estudiantes o sea ¡un congreso representativo de el uno por ciento de los estudiantes universitarios del país!"62 Aunque en ese Congreso se ratificaría la política reformista, por ejemplo se pedirían por el retronó de la autonomía universitaria ${ }^{63}$, y a mediados de 1968 la FUA encabezaría las celebraciones por el cincuenta aniversario de la gesta estudiantil, se criticaba estar rompiendo con el reformismo. En definitiva, estas críticas daban cuenta que el PCA pasaba a ser tras años en la conducción de la FUA una pequeña minoría frente a una dirección que decía identificarse con el verdadero comunismo, hecho que confirma la dimensión de la ruptura en este ámbito. Ello lo reconocía este documento partidario: "Sin duda, su principal trabajo y su principal daño lo han hecho en la Universidad, único lugar donde han encontrado puntos de apoyo.",64

\section{Conclusiones}

Tras la ruptura iniciada en septiembre de 1967 se constituyó a comienzos de año siguiente el Partido Comunista Comité Nacional de Recuperación Revolucionaria, justo cuando el PCA cumplía cincuenta años de vida. Según quien se convertiría en el líder de los escindidos, la ruptura abarcó a 4.000 militantes, aunque otros señalan que en realidad fue un poco menos de la mitad. ${ }^{65}$ Todos reconocen, sin embargo, la centralidad de los universitarios en este hecho, siendo el centro de la escisión la Capital Federal que vacío de militantes al PCA en la UBA. En marzo de 1969 los escindidos conformaron el Partido Comunista Revolucionario (PCR), abandonando ya la idea de que era posible ganar más adeptos en las filas del viejo partido. Tres año más tarde, el PCR asumió la ideología maoísta, algo que en los orígenes se había condenado. No todos, por cierto, de los que habían roto con el PCA terminaron allí. Hubo quienes tomaron otros caminos, como

\footnotetext{
62 "Asimilar, difundir y...", p. 42

${ }^{63}$ Carlos Ceballos. Los estudiantes universitarios y la política (1955-1970). Buenos Aires: CEAL, 1985, p. 117.

64 “Asimilar, difundir y...", p. 42.

${ }^{65}$ Para lo primero, Jorge Brega, p. 34. El testimonio divergente con éste pertenece a Sergio Rodríguez, recogido por Gilbert, p. 542. Es llamativo, por otro lado, que Oscar Arévalo al realizar una nueva historia oficial del PCA haya calificado de limitada la ruptura que produjo el grupo faccional sin dedicarle una línea más. El Partido Comunista. Buenos Aires: CEAL, 1983, p. 112.
} 
aquellos que confluyeron en las Fuerzas Armadas de Liberación. ${ }^{66}$ A diferencia de las rupturas de comienzos de los sesenta, que no pasaron de articular alternativas en el campo cultural, lo significativo de esta escisión es que los disidentes prosperaron en el terreno político, convirtiéndose en un competidor por izquierda del PCA.

Este artículo se ha dedicado, más específicamente, a explicar el proceso de ruptura que dio vida a estas organizaciones políticas de lo que se suele denominar la "nueva izquierda". Sin dudas este proceso no puede explicarse en escala nacional, sino que fue parte de un período revolucionario mundial en el que el protagonismo de la juventud resultó incuestionable. En este marco, formaciones anteriores de la izquierda como el comunismo sufrieron escisiones frente a otras que se planteaban como superadoras de un programa y una práctica que juzgaban moderados, y por lo tanto fuera de época.

En este clima de contestación a escala planetaria tampoco es una novedad el peso que alcanzaron los universitarios entre los jóvenes. En el caso argentino que ha tratado este artículo se ha enfatizado la preeminencia de la cuestión universitaria para entender la ruptura juvenil que vivió el PCA a mediados de 1967. El predominio de estos estudiantes en la escisión no es, claro está, en sí mismo una tesis novedosa. Los propios documentos de la ruptura analizados ponen, como se mostró, en el centro a este sujeto. Vargas ha enfatizado el tenor de la ruptura en el ámbito universitario, y particularmente en la ciudad de Buenos Aires donde el PCA se quedó prácticamente sin militantes en la UBA. Más recientemente, el periodista Gilbert en su historia de la FJC argentina lo ha reiterado.

Lo que constituye un aporte de este artículo es haber indagado con énfasis en la cuestión universitaria para explicar más acabadamente la ruptura, corriéndonos del uso de los testimonios como fuente principal de este proceso de ruptura. Si bien los discursos posteriores de militantes constituyen un complemento de la investigación, traen también aparejados problemas y rencillas personales de circunstancias históricas distintas a la de mediados de 1967, que es lo que sí se investigó aquí para explicar efectivamente la división partidaria. En pos de ofrecer un relato más fidedigno sobre este proceso de separación, se necesitó reunir los documentos que fueron reflejando la ruptura e imbuirse al mismo tiempo en los enfrentamientos sociales que protagonizaron estos universitarios, su trayectoria militante concreta, lo cual pudo reconstruirse a partir de un considerable trabajo de archivo.

Como se vio, tras la intervención del gobierno de Onganía a las universidades públicas, la militancia estudiantil reformista experimentó un revés significativo. Si bien en un primer momento los comunistas creyeron estar frente a la posibilidad de acabar pronto con esta intervención, ello finalmente no sucedió. Por el contrario, 1967 resultó un año donde la conflictividad universitaria, en sintonía con la conflictividad laboral, retrocedió notablemente. En este contexto, los malestares preexistentes se potenciaron. Desde el PCA, tenebrosos de que el proceso pusiera en jaque a la vieja dirección, se anuló todo debate interno al decidir apartar a los dirigentes díscolos. Como resultado de ello las posiciones de sus adversarios se tensaron, resolviendo los jóvenes críticos dar la batalla interna. Finalmente, dado que adentro era imposible ganar, progresivamente fueron marchándose hasta conformar su propia organización.

Los procesos sociales son multicausales. Señalar lo decisivo de la cuestión universitaria para explicar esta ruptura comunista reafirma este carácter dado que bajo el malestar universitario mundial se han registrado numerosas motivaciones que van de lo meramente generacional hasta explicaciones más complejas que tratan de sumar la estructura de clase y sus variaciones y el fin del ciclo del desarrollo capitalista de

${ }^{66}$ Al respecto véase Stella Grenat. Una espada sin cabeza. La FAL y la construcción del partido revolucionario en los '70. Buenos Aires: Razón y Revolución, 2010, p. 131 y ss. 
posguerra, los índices inéditos de bienestar entre los trabajadores, y, en Latinoamérica particularmente, el ciclo de dictaduras con la restricción de libertades públicas que trajeron consigo, para explicar la centralidad que adquirieron las luchas universitarias. Desde el ángulo adoptado en este trabajo, se ha mostrado que sin considerar el desenvolvimiento de la lucha de tales estudiantes, la parálisis en que se encontraban, no es posible explicar la ruptura más significativa que sufrió el PCA. Esta contribución, sin dudas, debe ser completada en el futuro por otros trabajos que den cuenta de la trayectoria de organizaciones que como el PCR afloraron en este proceso.

\section{Obras citadas}

Arévalo, Óscar: El Partido Comunista. Buenos Aires: CEAL, 1983

Bonvillani, Paola. 'Unidad contra la dictadura 'corporativo fascista': algunas lectura del Partido Comunista sobre el golpe de Estado de 1966". Revista Izquierdas. Una mirada histórica desde América Latina, $\mathrm{n}^{\mathbf{0}}$ 22, Instituto de Estudios Avanzados de la Universidad de Santiago de Chile. Santiago de Chile, enero de 2015, pp. 110-132.

Brega, Jorge. ¿Ha muerto el comunismo? El maoísmo en la Argentina. Entrevista con Otto Vargas. Buenos Aires: Ediciones Brega, 1990.

Califa, Juan Sebastián. "Los estudiantes comunistas frente a la reestructuración de la Universidad de Buenos Aires (1955-1958)". Estudios Sociales, año XX. Santa Fe: Universidad Nacional del Litoral, primer semestre de 2010, pp. 127-150.

Califa, Juan Sebastián. Reforma y Revolución. La radicalización política del movimiento estudiantil de la UBA 1943-1966. Buenos Aires: Eudeba, 2014.

Camarero, Hernán. "La izquierda como objeto historiográfico. Un balance de los estudios sobre el socialismo y el comunismo en la Argentina". Nuevo Topo. Revista de Historia y Pensamiento Crítico, $\mathrm{n}^{\mathrm{o}} 1$. Buenos Aires, septiembre- octubre de 2005, pp. 77-99.

Camarero, Hernán. "Tras las huellas de una ilusión: El Partido Comunista Argentino y sus planteos del Frente Democrático Nacional (1955-1963)". Archivos de historia del movimiento obrero y la izquierda, año III, $n^{\circ}$ 5. Buenos Aires, septiembre de 2014, pp. $31-50$.

Campione, Daniel. "El Partido Comunista de la Argentina. Apuntes sobre su trayectoria". Elvira Concheiro Borquez, Massimo Modonesi y Horacio Crespo (coords.). El comunismo: otras miradas desde América Latina. México D.F.: UNAM, 2007, pp. 167-215.

Caruso, Marcelo. "La amante esquiva: comunismo y reformismo universitario en Argentina (1918-1966). Una introducción”. Renate Marsiske (comp.). Movimientos 
estudiantiles en la historia de América Latina, volumen II. México D.F.: Plaza y Valdés, 1999, pp. 123-162.

Ceballos, Carlos. Los estudiantes universitarios y la política (1955-1970). Buenos Aires: CEAL, 1985.

Cernadas, Jorge, Horacio Tarcus y Roberto Pittaluga. "La historiografía sobre el partido comunista de la Argentina. Un estado de la cuestión". El Rodaballo. Revista de política y Cultura, año IX, nº 8. Buenos Aires, otoño-invierno de 1998, pp. 30-39.

De Riz, Liliana. La política en suspenso 1966-1976. Buenos Aires: Paidós, 2000.

Ferrero, Roberto. Historia Crítica del Movimiento Estudiantil de Córdoba tomo III (1955-1973). Córdoba: Alción, 2009.

Gilbert, Isidoro. La Fede. Alistándose para la revolución. La Federación Juvenil Comunista 1921-2005. Buenos Aires: Sudamericana, 2009.

Gordillo, Mónica. "Protesta, rebelión y movilización: de la resistencia a la lucha armada, 1955-1976". Daniel James (dir.). Nueva Historia Argentina. Violencia, proscripción y autoritarismo (1955-1976). Tomo IX. Buenos Aires: Sudamericana, 2007, pp. 329-380.

Grenat, Stella. Una espada sin cabeza. La FAL y la construcción del partido revolucionario en los '70. Buenos Aires: Razón y Revolución, 2010.

Kleiner, Bernardo. Veinte años del movimiento estudiantil reformista 1943-1963. Buenos Aires: Platina, 1964.

Massholder, Alexia: El Partido Comunista y sus intelectuales. Pensamiento y acción de Héctor P. Agosti. Buenos Aires: Ediciones Luxemburg, 2014.

Mignone, Emillio. Política y Universidad. El Estado legislador. Buenos Aires: Lugar Editorial, 1998.

O’ Donnell, Guillermo. El Estado Burocrático Autoritario 1966-1973. Triunfos, derrotas y crisis. Buenos Aires: Prometeo, 2009.

O' Donnell, Guillermo. "Estado y alianzas en la Argentina". Desarrollo Económico. Revista de Ciencias Sociales, vol. 16, nº 64. Buenos Aires, enero-marzo de 1977, pp. 523-554.

Portantiero, Juan Carlos. "Clases dominantes y crisis política en la Argentina actual". Oscar Braun (comp.). El capitalismo argentino en crisis. Buenos Aires: Siglo Veintiuno, 1973, pp. 73-117.

Prado Acosta, Laura. “Sobre lo 'viejo' y lo 'nuevo': el Partido Comunista Argentino y su conflicto con la Nueva Izquierda en los años sesenta". A Contracorrientes. A Journal 
on Social History and Literature in Latin America, North Carolina State University, vol. $11, \mathrm{n}^{\circ} 1$. North Carolina: Raleigh, pp. 68-85.

Romero, José Luis. Breve Historia Contemporánea de la Argentina. Buenos Aires: Fondo de Cultura Económica, 1994.

Sigal, Silvia: Intelectuales y poder en la década del sesenta. Buenos Aires: Puntosur, 1991.

Slemenson, Marta. Emigración de científicos argentinos: organización de un éxodo a América Latina. Buenos Aires: Instituto Torcuato Di Tella, 1970.

Tortti, María Cristina. 'Izquierda y 'nueva izquierda' en la Argentina. El caso del Partido Comunista". Sociohistórica. Cuadernos del CISH, $\mathrm{n}^{\circ}$ 6, Centro de Investigaciones SocioHistóricas, Facultad de Humanidades y Ciencias de la Educación, UNLP. La Plata: Al Margen, $2^{\circ}$ semestre de 1999, pp. 221-232.

Tortti, María Cristina. "Debates y rupturas en los partidos Comunista y Socialista durante el frondizismo". Prismas. Revista de historia intelectual, UNQui, nº 6. Quilmes, 2002, pp. 265-274.

Tortti, María Cristina. El 'viejo' Partido Socialista y los orígenes de la 'nueva izquierda (1955-1966). Buenos Aires: Prometeo, 1999.

Ubertalli, Jorge Luis. El enemigo rojo. La represión al comunismo en la Argentina. Buenos Aires: Acercándonos Ediciones, 2010.

\section{Archivos consultados}

Archivo del Partido Comunista Argentino.

Biblioteca del Centro Cultural de la Cooperación "Floreal Gorini”.

Centro de Documentación e Investigación de la Cultura de Izquierdas en Argentina (CEDINCI).

\section{Fuentes primarias analizadas}

Base de datos de Capital Federal para el periodo 1966-1967 confeccionada por Pablo Bonavena (construida a partir de los diarios porteños Crónica, Clarín, La Nación y La Prensa).

Cuadernos de Cultura, 1966-1968.

Documentos del PCR. Desde la ruptura con el PC revisionista hasta el Primer Congreso del PCR realizado del 11 al 14 de diciembre de 1969. Tomo 1. Buenos Aires: Edición del Partido Comunista Revolucionario (PCR). 
Juventud. Órgano de la Federación Juvenil Comunista, 1966-1968.

Línea. Periódico de los estudiantes universitarios comunistas, 1966-1968.

Nueva Era Revista Teórico-política del Partido Comunista de la Argentina, 1966-1968.

Nuestra Palabra. Órgano del Partido Comunista, 1966-1968.

Nueva Hora. Órgano del Partido Comunista Comité Nacional de Recuperación Revolucionaria, 1968.

Primera Plana, 1966-1967

Recibido: 7 abril 2015 Aprobado: 2 junio 2015 